Case Report

\title{
RARE DISTINCT SUBTYPE OF CLEAR CELL RENAL CELL CARCINOMA - MULTILOCULAR CYSTIC RENAL CELL CARCINOMA
}

\author{
Jayaprakash Shetty K, Chandrika, J.H. Makannavar, Kishan Prasad H.L, Rajeev T.P ${ }^{1}$ \\ ${ }^{1}$ Department of Pathology and Department of Urology, K.S. Hegde Medical Academy, \\ Deralakatte, M angalore 575018, Karnataka, India \\ Correspondence: \\ Jayaprakash Shetty, \\ Professor and Head, Department of Pathology, \\ K.S. Hegde M edical Academy, M angalore 575018, Karnataka, India. E-mail : drjpshetty9@ yahoo.com
}

\begin{abstract}
:
Multilocular cystic renal cell carcinoma (M CRCC) is an uncommon low- grade tumor with unique morphologic features and excellent prognosis. Currently it is classified as subtype of clear cell renal cell carcinoma. We report a case of multilocular cystic renal cell carcinoma presented with right renal mass. Computed tomography showed heterogeneously enhancing partly cystic mass lesion in right kidney. Patient underwent right nephrectomy. Microscopic features were suggestive of multilocular cystic renal cell carcinoma. Patient is doing well with no evidence of recurrence.
\end{abstract}

Keywords: cystic renal cell carcinoma, renal cell carcinoma

\section{Introduction}

Multilocular cystic renal cell carcinoma is a rare variant of clear cell carcinoma comprising of approximately 1 to $2 \%$ of all renal tumors with good prognosis. ${ }^{1,2}$ Various cystic diseases of the kidney such as multilocular cystic renal cell carcinoma, cystic nephroma, mixed epithelial and stromal tumor of the kidney may present with similar findings on imaging and are difficult to distinguish. ${ }^{3}$ Clinically, M CRCC behaves as a low grade variant of renal cell carcinoma in $83-88 \%$ of cases and have a good prognosis. ${ }^{2}$

\section{Case report}

We report a case of a 40 year old man presented with the complaints of mass in the right loin and frequency of mictuirition since two months. Computed tomography abdomen showed a heterogenously enhancing partly cystic mass in the lower pole of the right kidney measuring $5 \times 4 \mathrm{~cm}$.(figure 3 ) Nephrectomy specimen showed tumor measuring $6.8 \times 5 \mathrm{~cm}$ that occupied lower pole. The cut section showed multiloculation with cysts ranging from $2 \mathrm{~mm}$ to $2 \mathrm{~cm}$ in diameter filled with mucoid fluid.(Figure 1)M icroscopy showed a multicystic tumor with tumor cells having clear cytoplasm with hyperchromatic nuclei with anisonucleosis and no visible nucleoli (Fuhrman nuclear grade I).These tumor cells were separated by delicate fibrovascular septa. (Figure 2) Renal capsule, vessels and perinephric fat were free of tumor. A diagnosis of Multilocular cystic renal cell carcinoma, Fuhrman nuclear grade I(stage 1) was made. Patient is well with no evidence of recurrence after three years of follow up

\section{Discussion}

MCRCC is a subtype of clear cell renal cell carcinoma with distinct morphology. ${ }^{4} \mathrm{M}$ ain pathological features of M CRCC, according to the WHO classification of kidney tumors are on gross are multilocular cystic appearance , encapsulated, yellowish solid component limited to small areas, no expansile nodules, and tumor necrosis is absent with microscopy showing cyst lined by cuboidal clear cells or flattened epithelium, septa containing aggregates of epithelial cells with clear cytoplasm and low Fuhrman grade. ${ }^{6}$

The term multilocular cystic renal cell carcinoma should be used exclusively to identify cystic renal cell carcinoma 
be used exclusively to identify cystic renal cell carcinoma with a small volume ( $25 \%$ or less) of neoplastic clear cells in the cyst wall. 2, 3, 5 The differential diagnosis of multilocular cystic mass includes multilocular cystic nephroma and mixed epithelial and stromal tumor of the kidney. Multilocular cystic nephroma is a benign entity, characterized by communicating cysts of variable size separated by fibrous septa. Cystic nephroma in adults is considered to belong to the spectrum of cystic renal lesions, ranging from typical cystic nephroma to mixed epithelial and stromal tumor of the kidney. ${ }^{2}$ On US and CT images, M CRCC appears as a well defined, multilocular cystic mass with serous, proteinaceous or hemorrhagic fluid, with no expansile solid nodules in the thin septa and sometimes with small, slightly solid areas. ${ }^{7}$ When the

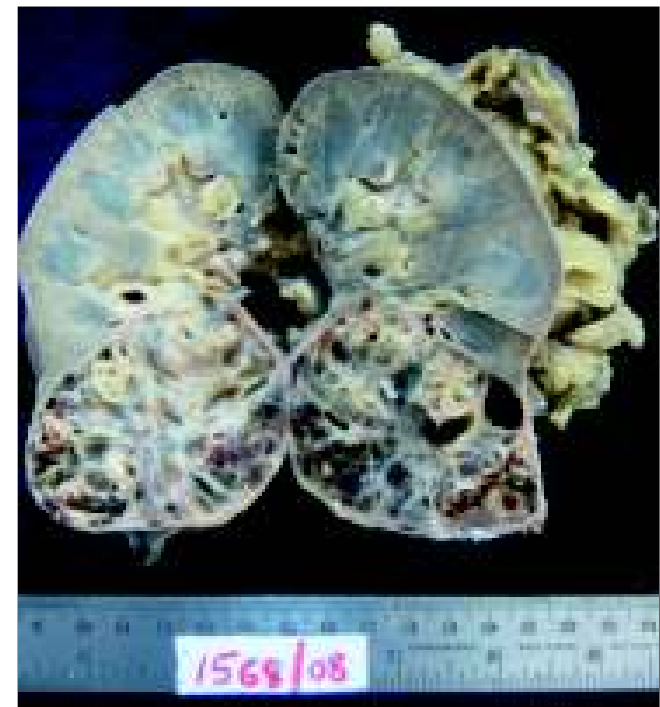

Figure 1 -Right nephrectomy specimen showing cystic tumor in the lower pole of the kidney.

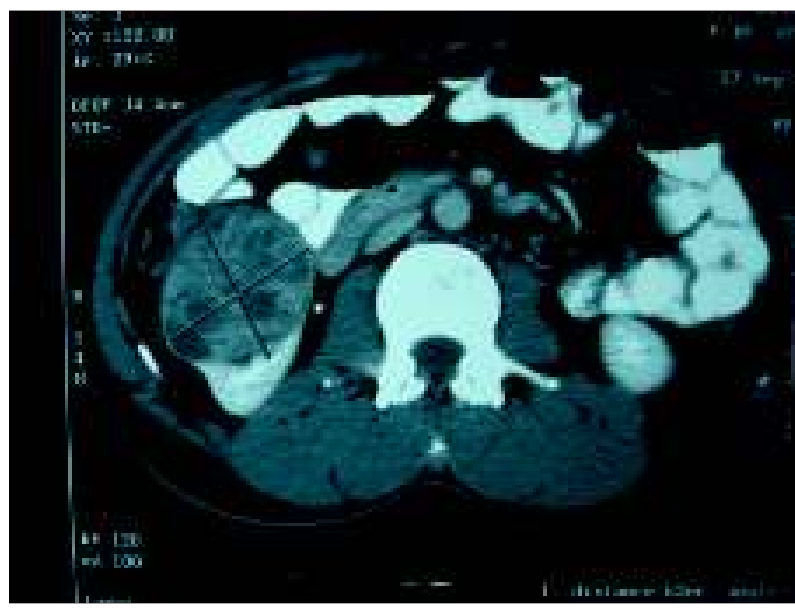

radiological examination demonstrate a cystic renal mass of this kind in adult males, MCRCC should be included in the differential diagnosis. ${ }^{3}$

Shams $\mathrm{H}$ et al study observed chromosome $3 p$ deletion in M CRCC which provides support for the hypothesis that it is a subtype of clear cell renal cell carcinoma. ${ }^{4}$

Multilocular cystic renal cell carcinoma has a better outcome than non cystic conventional renal cell carcinoma. ${ }^{6}$ The tumor has extremely high cure rate, ranging from 92 - 100\% following surgical resection. ${ }^{2,4}$ Hence, few authors have suggested renaming it as multilocular cystic renal cell carcinoma of low malignant potential. ${ }^{2,3}$

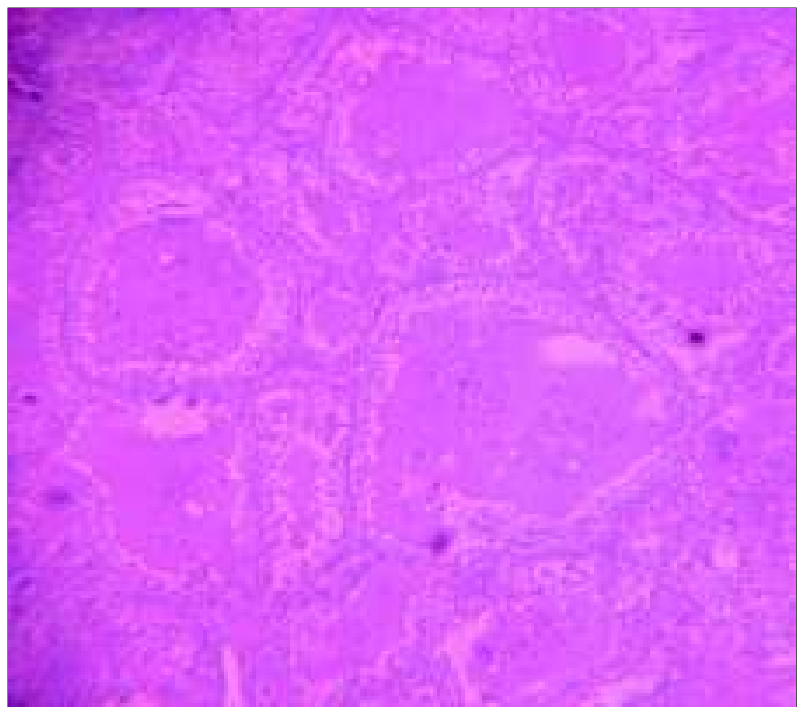

Figure 2 -M ulticystic tumor with tumor cells having clear cytoplasm.
Figure 3 -C T image showing heterogeneously enhancing cystic mass in the lower pole of right kidney. 


\section{References}

1. Murphy WM, Grignon DJ, Perlman EJ. Kidney tumors in adults. In: Tumors of the Kidney, Bladder, and related Related Urinary Structures. Washington, DC: American Registry of Pathology; 2004:121-123. AFIP Atlas of Tumor Pathology; $4^{\text {th }}$ series, fascicle 1.

2. Swetha A, Usha A, Mohanty NK, Sunita S.Multilocular Cystic Renal Cell Carcinoma: A Case Report of a Rare Entity. Arch Pathol Lab Med.2011;135:291-292.

3. Abha S, Andleeb A, ritesh S, Anu C, Anita V. Multilocualr cystic renal cell carcinoma. Indian Journal of Pathology and Mirobiology.2008;51(3):457458.
4. Shams H, John NE, David JG, Antonio L-B, Rudolfo M, Puay-Hoon T, M ingsheng W, Shaobo Z, Gregory TM , Liang C. M ultilocualr cystic renal cell carcinoma is a subtype of clear cell carcinoma. Modern Pathology. 2010; 23:931-936.

5. Nasir A, Jollimore J, Gupta R, Bell D, Norman R. M ultilocular cystic renal cell carcinoma: a series of 12 cases and review of the literature. Urology. 2002;60(3):421-427.

6. Sueli Suzigan et al. Multilocular Cystic Renal Cell Carcinoma. A report of 45 cases of a Kidney Tumor of Low Malignant Potential. Am J Clin Pathol 2006;125:217-222.

7. Mohapatra TP, Rath RC, Panigrahi KK. Multilocular cystic renal cell carcinoma( M LRCC): A rare clinical entity. Indian J Urol 2002;18:152-153. 